\title{
LEVINSON'S INEQUALITY FOR HILBERT SPACE OPERATORS
}

\author{
JADRANKA MićIĆ, Josip PEČARIĆ AND MARJAN PRALJAK
}

Abstract. Levinson's operator inequality is given for unital fields of positive linear mappings and a large class of functions. Order among quasi-arithmetic means is considered under similar conditions.

Mathematics subject classification (2010): Primary 47A63; Secondary 47B15, 47A64.

Keywords and phrases: Self-adjoint operator, positive linear mapping, convex function, Levinson's inequality, quasi-arithmetic mean.

\section{REFERENCES}

[1] I. A. Baloch, J. PeČarić And M. Praljak, Generalization of Levinson's inequality, J. Math. Inequal., acceptted for publication.

[2] P. S. Bullen, An inequality of N. Levinson, Univ. Beograd. Publ. Elektrotehn. Fak. Ser. Mat. Fiz. 412-460 (1973), 109-112.

[3] T. FujiI, J. Mićić Hot, J. PeČarić And Y. SEO, Recent Developments of Mond-Pečarić Method in Operator Inequalities, Monographs in Inequalities 4, Element, Zagreb, 2012.

[4] T. Furuta, J. Mićić Hot, J. Pečarić And Y. Seo, Mond-Pečarić Method in Operator Inequalities, Monographs in Inequalities 1, Element, Zagreb, 2005.

[5] N. Levinson, Generalization of an inequality of Ky Fan, J. Math. Anal. Appl. 8 (1964), 133-134.

[6] A. MCD. MERCER, Short proof of Jensen's and Levinson's inequalities, Math. Gazette 94 (2010), 492-495.

[7] J. MIćIĆ, Refinements of quasi-arithmetic means inequalities for Hilbert space operators, Banach J. Math. Anal. 9 (2015), 111-126.

[8] J. Mıćıć, K. Hот, Inequalities among quasi-arithmetic means for continuous field of operators, Filomat, 26:5 (2012), 977-991.

[9] J. MiĆIĆ, Z. PAVIĆ AND J. PEČARIĆ, Jensen's inequality for operators without operator convexity, Linear Algebra Appl. 434 (2011), 1228-1237.

[10] M. S. Moslehian, J. Mićić AND M. KiAn, An operator inequality and its consequences, Linear Algebra Appl. 439 (2013) 3, 584-591.

[11] T. PopoviciU, Sur une inegalite de N. Levinson, Mathematica (Cluj) 6 (1964), 301-306.

[12] A. Witkowski, On Levinson's inequality, RGMIA Research Report Collection 15 (2012), Article 68.

[13] A. Witkowski, On Levinson's inequality, Ann. Univ. Paed. Cracov. Stud. Math. 12 (2013), 59-67. 